\title{
Portal hypertension-associated gastric polyps
}

\author{
Jason Timothy Boyd, ${ }^{1}$ Lennard Lee ${ }^{2}$
}

'Milton Keynes NHS

Foundation Trust, Oxford, Oxfordshire, UK

${ }^{2}$ Milton Keynes NHS Foundation Trust, Milton Keynes, UK

\section{Correspondence to} Dr Jason Timothy Boyd, jasonboyd@doctors.org.uk

\section{DESCRIPTION}

A 57-year-old man with a new diagnosis of alcoholic cirrhosis underwent a routine screening endoscopy to investigate the presence of varices. Gastroscopic examination was performed up to the second part of the duodenum. Examination of the gastric mucosa revealed the presence of over 30 pedunculated and subpeduculated lesions (figures 1 and 2). Biopsies demonstrated superficial polypoid glandular mucosa (figure 3 ).

Gastric polyps are found in 3-6\% of patients undergoing gastroscopic examination and they often give rise to concern. The most common polyps are fundic gland and hyperplastic types, comprising $77 \%$ and $17 \%$, respectively. Adenomas are relatively rare, making up $<1 \%$ of detected polyps. $^{1}$

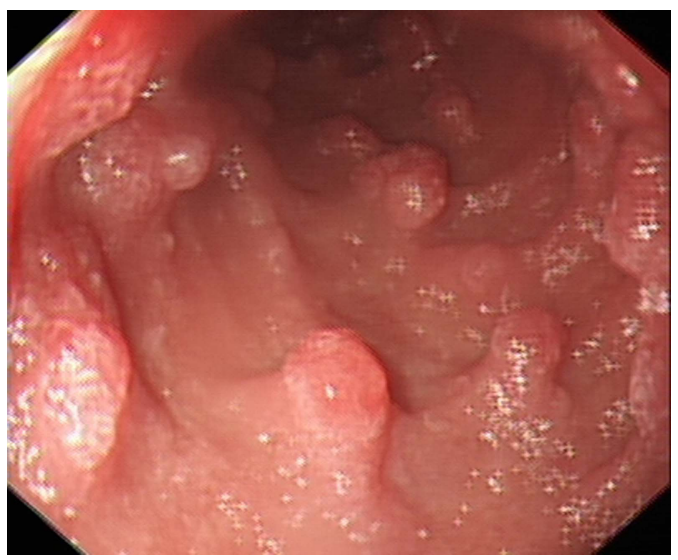

Figure 1 Photograph of the body of the stomach taken during routine screening gastroscopy.

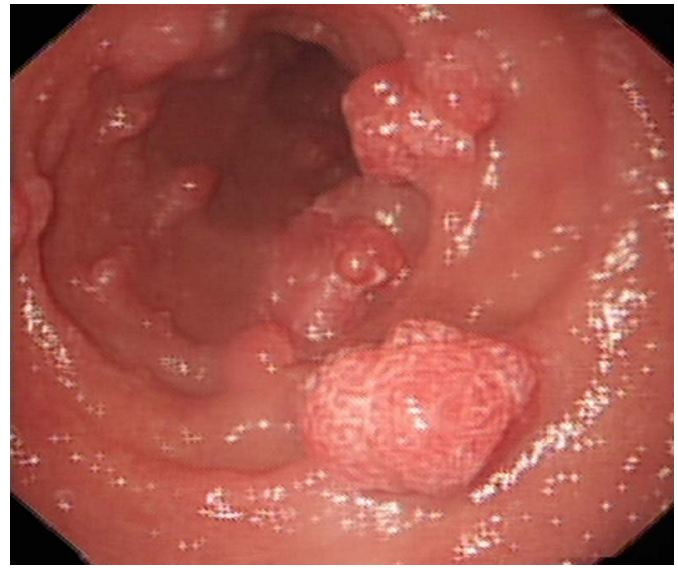

Figure 2 Photograph of the body of the stomach taken during routine screening gastroscopy.

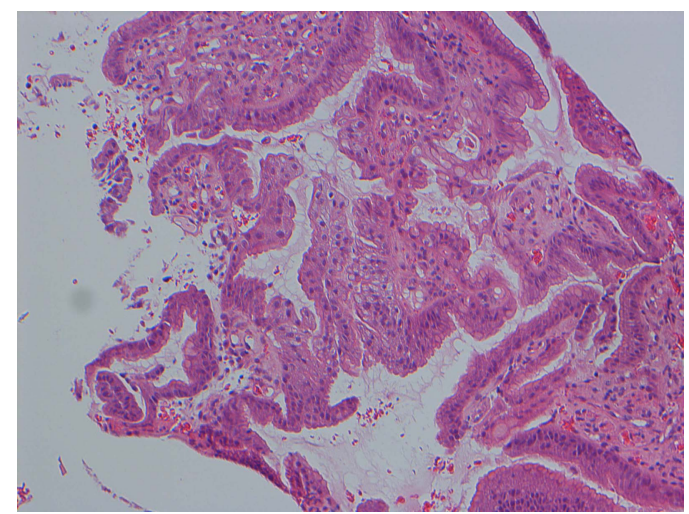

Figure 3 Histopathological image of the polyp biopsied during routine screening endoscopy.

Fundic gland polyps have a very low malignant potential and can be reliably identified based on endoscopic features. Hyperplastic polyps are associated with chronic inflammation, most commonly due to Helicobacter pylori gastritis. They also have a low malignant potential, but may be associated with malignancy elsewhere in the gastric mucosa. ${ }^{2}$ Gastric adenomas are premalignant and should be excised.

The relative rarity of gastric adenomas, but high risk of neoplastic progression, means that the management of gastric polyps is controversial. Many centres advocate polypectomy for all small gastric polyps and repeat biopsy of larger polyps at 1 year. Others recommend that as larger polyps have the greatest malignant potential, polypectomy should only be performed on large gastric polyps. The latter is the standard practice at our centre.

This image is of particular importance as it demonstrates that portal hypertension is associated with an increased number of gastric polyps, hence the term portal hypertension-associated gastric polyps. Although they have a similar endoscopic appearance to hyperplastic polyps, they are believed to have a different aetiology. Histopathological examination reveals mucosal hyperplasia and vascular proliferation. Formation may be due to mucosal injury that is vascular in nature. Their malignant potential has not been fully elucidated, however, lesions can grow to a large size. ${ }^{3}$

Patients with portal hypertension are at increased risk of postpolypectomy bleeding and other complications of polypectomy. ${ }^{3}$ Surveillance is likely to be safer than multiple polypectomies, therefore in patients with portal hypertension it is essential that gastric polyps are photographed and biopsied during routine surveillance gastroscopies. 


\section{Learning points}

- The aetiology of portal hypertension-associated polyps may be vascular in nature.

- Polyps in patients with portal hypertension should be photographed and biopsied during routine surveillance gastroscopies.

- Surveillance is likely to be safer than multiple polypectomies in patients with portal hypertension.
Competing interests None.

Patient consent Obtained.

Provenance and peer review Not commissioned; externally peer reviewed.

\section{REFERENCES}

1 Carmack SW, Genta RM, Schuler CM, et al. The current spectrum of gastric polyps: a 1-year national study over 120,000 patients. Am I Gastroenterol 2009;104:1524-32.

2 Goddard AF, Badreldin R, Pritchard MD, et al. The management of gastric polyps. Gut 2010;59:1270-6.

3 Lam MCW, Tha S, Owen D, et al. Gastric polyps in patients with portal hypertension. Eur I Gastroenterol Hepatol 2011;23:1245-9.

Copyright 2014 BMJ Publishing Group. All rights reserved. For permission to reuse any of this content visit http://group.bmj.com/group/rights-licensing/permissions.

BMJ Case Report Fellows may re-use this article for personal use and teaching without any further permission.

Become a Fellow of BMJ Case Reports today and you can:

- Submit as many cases as you like

- Enjoy fast sympathetic peer review and rapid publication of accepted articles

- Access all the published articles

- Re-use any of the published material for personal use and teaching without further permission

For information on Institutional Fellowships contact consortiasales@bmjgroup.com

Visit casereports.bmj.com for more articles like this and to become a Fellow 